DOI.

https://doi.org/10.22219/fths.v2i2

Received: Mei 2019

Accepted: Juni 2019

Available online: Juli 2019

\title{
Kualitas Ikan Lele Dumbo (Clarias Gariepinus) Asin Kering Menggunakan Metode Dry Salting dan Wet Salting Dengan Konsentrasi NaCl Yang Berbeda
}

\author{
Zainal Muhtadi1, Wehandaka Pancapalaga ${ }^{2}$, Mochammad Wachid ${ }^{*}$ \\ ${ }^{1}$ Program Studi Teknologi Pangan, Fakultas Pertanian Peternakan, Universitas Muhammadiyah \\ Malang, Malang, Indonesia \\ ${ }^{2}$ Dosen Jurusan Peternakan, Fakultas Pertanian-Peternakan, Universitas Muhammadiyah \\ Malang \\ *Corresponding author email: mochammadwachid3@umm.ac.id
}

\begin{abstract}
The production of catfish in East Java in recent years increased significantly from 96,337.2 tons in 2014, to 113,070,4 tons in 2015. The high production impact on difficulties of farmers in some areas in marketing their crops, consequently many farmers lose money because feed stocks continue to go while the harvest difficulties sales. One way to increase market interest is by processing it into salted fish products trough salting method, there are two kinds of salting methods, including Wet salting and Dry salting. However, not all salting techniques produce a guaranteed quality product, this is due to the absence of definite dose for the amount of ingredients used, so determining the right $\mathrm{NaCl}$ concentration is essential to create a high quality dried salted fish product. The aim of this research is to know the effect of Salting method and different $\mathrm{NaCl}$ concentration on the quality of dried catfish. This research uses experimental method with Randomized Block Design (RBD) pattern factorial. Factor I: salting method consisting of Z1: Dry salting Z2: Wet salting. Factor II: NaCl concentration consisting of M1: 15\%, M2: 25\%, M3: $35 \%$, M4: 45\% So that there are 8 treatment variables, and each repeated 3 times so that there are 24 treatments. The parameters tested include $\mathrm{NaCl}$, water, ash insoluble in acid, total plate count, protein, fat, and organoleptic (taste, appearance, aromatic, texture). The results of this study indicate that there is an interaction between the use of different types of salting methods and $\mathrm{NaCl}$ concentration on $\mathrm{NaCl}$ content, water, ash insoluble in acid, total plate count, and organoleptic taste. But there is no interaction with parameters protein, fat, organoleptic appearance, aromatic and texture. Based on the physico-chemical and organoleptic properties of dried salted catfish we found the best total treatment on Z1M4 (Dry salting: $\mathrm{NaCl} 45 \%$ concentration) with NaCl 15.44\%, Water 16.67\%, Ash Insoluble in Acid 0.21\%, Total Plate Count $1.1 \times 10^{4}$, Protein 25.27\%, Fat 6.06\%, Organoleptic (taste) 5, Organoleptic (Appearance) 7.08, Organoleptic (Aromatic) 6.92, Organoleptic (Texture) 7.67.
\end{abstract}

Keywords: Catfish, Dry Salting, Wet Salting, Dried Salty Catfish.

\section{PENDAHULUAN}

Produksi ikan lele di Jawa timur dari berbagai teknik budidaya dalam beberapa tahun terakhir meningkat cukup signifikan dari 96.337.2 ton tahun 2014, menjadi 113.070.4 ton tahun 2015 dan akan terus meningkat pada 
beberapa tahun kedepan (DKP Jatim, 2016). Tingginya jumlah produksi ikan lele ini berimbas pada sulitnya pembudidaya dibeberapa daerah dalam memasarkan hasil panennya, akibatnya banyak pembudidaya merugi karena stok pakan terus jalan sementara hasil panen kesulitan dalam penjualan. Oleh karena itu diperlukan proses pengolahan pasca panen untuk meningkatkan minat pasar, menambah nilai, baik dari segi gizi, rasa, bau, bentuk, maupun daya awetnya (Adawiyah, 2007)

Penanganan pasca panen yang dapat digunakan untuk meningkatkan minat pasar dan daya simpan dari ikan lele adalah dengan mengolahnya menjadi produk ikan asin melalui metode salting (penggaraman). Menurut Huss (1994), pengasinan adalah suatu proses pengolahan ikan dengan cara memberikan garam sehingga mempunyai kandungan garam sangat tinggi yang kemudian dikeringkan. Ada dua macam metode salting dalam proses pengolahan ikan asin, diantaranya Wet salting dan Dry salting. Wet salting dilakukan dengan cara merendam ikan dalam larutan garam sedangkan Dry Salting dilakukan dengan cara melapis daging ikan dengan garam. Dari kedua metode ini tentunya ada perbedaan hasil kualitas produk akhir, namun saat ini masih belum banyak penelitian yang mengarah pada perbandingan nilai efektivitas dalam menentukan mutu akhir ikan asin dari kedua metode ini.

Pemakaian Konsentrasi $\mathrm{NaCl}$ menjadi salah satu hal yang sangat penting dalam proses penggaraman karena dari masing-masing konsentrasi menghasilkan kualitas ikan asin yang berbeda. Berdasarkan pemaparan diatas, maka perlu adanya uji untuk mengetahui pengaruh dua metode Dry salting dan Wet salting dengan konsentrasi $\mathrm{NaCl}$ terhadap kualitas ikan lele asin kering. Karena itu, peneliti ingin melakukan penelitian dengan judul : "kualitas ikan lele dumbo (Clarias gariepinus) asin kering menggunakan metode dry salting dan wet salting dengan konsentrasi NaCL yang berbeda" Sehingga dapat diketahui tingkat efektivitas dari kedua metode ini dan konsentrasi $\mathrm{NaCl}$ yang optimal agar terciptanya produk ikan lele asin kering yang berkualitas tinggi.

\section{METODE PENELITIAN}

\section{Bahan}

Bahan-bahan yang digunakan dalam penelitian ini yaitu : ikan lele jenis Dumbo dengan kisaran bobot 120-150 gram/ekor dan umur 2,5-3 bulan yang diperoleh dari bapak Purnomo petani didesa Jetak Lor, NaCl (garam grasak kemurnian 90-95\%).

Alat

Alat - alat yang digunakan dalam penelitian ini yaitu timbangan analitik, cabinet dryer, autoklaf, inkubator, spektofotometer. 
Pembuatan Ikan asin kering ini metode Dry Salting berdasarkan SNI 2721 [1].1-2009

Tahapan pembuatan ikan asin kering ini diawali dengan proses penyortiran ikan dengan kriteria fisik terlihat normal dan kisaran bobot 120-150 g/ekor, kemudian dilakukan pembuangan kepala, usus dan pembelahan ikan menjadi dua bagian, setelah itu dilakukan pencucian untuk membersihkan kotoran, lendir, darah. Ikan yang telah bersih kemudian digarami menggunakan $\mathrm{NaCl}$ (garam grasak kemurnian berkisar 90-95\%) dengan cara penamburan secara langsung dan dibiarkan selama $\pm 7 \mathrm{jam}$, penggunaan penggaraman selama 7 jam ini didasarkan pada hasil perlakuan terbaik pada penelitian Roberto, dkk (2013), dengan judul "pengaruh konsentrasi garam dan lama penggaraman terhadap nilai hedonik ikan bandeng asin kering" . kemudian dilakukan pencucian lagi untuk menghilangkan lendir dan darah, setelah itu dilakukan pengeringan menggunakan Cabinet dryer dengan suhu $70^{\circ} \mathrm{c}$ selama \pm 12 jam, penggunaan suhu $70^{\circ} \mathrm{c}$ selama \pm 12 jam ini juga didasarkan pada hasil perlakuan terbaik pada penelitian Riansyah dkk, (2013) dengan "pengaruh perbedaan suhu dan waktu pengeringan terhadap karakteristik ikan asin Sepat Siam dengan menggunakan oven". ikan yang telah kering kemudian di masukan dalam plastik PP untuk menghindari terjadinya kontaminasi sebelum dilakukan analisis.

Pembuatan Ikan asin kering ini metode Wet Salting berdasarkan SNI 2721 [1].12009

Tahapan pembuatan ikan asin kering metode ini diawali dengan proses pembuatan larutan garam dengan perbandingan ikan, air, garam 1:1:1 artinya (setiap $100 \mathrm{~g}$ ikan berisi $100 \mathrm{ml}$ air dan $100 \mathrm{~g}$ garam) penentuan jumlah garam dan air selalu didasarkan pada berat awal ikan. Setelah itu dilakukan penyortiran ikan dengan kriteria fisik terlihat normal dan kisaran bobot 120-150 g/ekor, ikan yang telah disortir kemudian dilakukan pembuangan kepala, usus dan pembelahan ikan menjadi dua bagian, setelah itu dilakukan pencucian untuk membersihkan kotoran, lendir, darah. Ikan yang telah bersih kemudian digarami menggunakan larutan $\mathrm{NaCl}$ (garam grasak kemurnian berkisar 90$95 \%$ ) dengan cara perendaman dan dibiarkan selama \pm 7 jam, penggunaan penggaraman selama 7 jam ini didasarkan pada hasil perlakuan terbaik pada penelitian Roberto, dkk (2013), dengan judul "pengaruh konsentrasi garam dan lama penggaraman terhadap nilai hedonik ikan bandeng asin kering" . kemudian dilakukan pencucian lagi untuk menghilangkan lendir dan darah, setelah itu dilakukan pengeringan menggunakan Cabinet dryer dengan suhu $70^{\circ} \mathrm{C}$ selama \pm 12 jam, penggunaan suhu $70^{\circ} \mathrm{c}$ selama \pm 12 jam ini juga didasarkan pada hasil perlakuan terbaik pada penelitian Riansyah dkk, (2013) dengan "pengaruh perbedaan suhu dan waktu pengeringan terhadap karakteristik ikan asin Sepat 
Siam dengan menggunakan oven”. ikan yang telah kering kemudian di masukan dalam plastik PP untuk menghindari terjadinya kontaminasi sebelum dilakukan analisis.

\section{Parameter Penelitian}

Parameter yang diuji dalam penelitian ini meliputi kadar protein, kadar air, kadar abu tidak larut asam, kadar lemak, kadar garam, dan total plate count (TPC), organoleptik (rasa, kenampakan, aroma, tekstur)

\section{Rancangan Percobaan dan Analisa Data}

Penelitian ini menggunakan metode percobaan dengan desain Rancangan Acak Kelompok (RAK) yang disusun secara faktorial. Faktor I : metode salting yang terdiri atas Z1: Dry salting Z2: Wet salting. Faktor II : konsentrasi $\mathrm{NaCl}$ yang terdiri atas M1: 15\%, M2: 25\%, M3: 35\%, 45\% Sehingga terdapat 8 Variabel perlakuan, dan kemudian masing-masing dilakukan pengulangan 3 kali sehingga terdapat 24 perlakuan.

Data yang diperoleh dari uji kadar $\mathrm{NaCl}$, air, abu tidak larut asam, total plate count, protein dan lemak dianalisa dengan ANOVA jika terdapat perbedaan nyata dilanjutkan dengan uji DMRT (Duncan's Multiple Range Test) dan data yang diperoleh pada uji organoleptik rasa, kenampakan, aroma dan tekstur dianalisa dengan Kruskall Wallis jika terdapat perbedaan secara nyata dilanjutkan dengan uji Mann Whitney guna menentukan level terbaik dari masing-masing.

\section{HASIL DAN PEMBAHASAN}

\section{Karakteristik Bahan Baku}

Analisa bahan baku pada penelitian ini meliputi kadar $\mathrm{NaCl}$, Kadar air, Kadar Abu Tidak Larut Asam, Total Plate Count (TPC), Kadar Protein, Kadar Lemak.

Tabel 1. Hasil Analisa Bahan Baku Ikan Lele Dumbo

\begin{tabular}{lcc}
\hline Komponen & Literatur & Ikan Lele Segar \\
\hline Kadar NaCl (\%) & - & 0 \\
Kadar Air (\%) & 75,68 & 74,90 \\
Kadar Abu Tidak Larut Asam (\%) & - & 0 \\
Total Plate Count (Cfu/ml) & - & $3,07 \times 10^{5}$ \\
Kadar Protein (\%) & 16,80 & 13,17 \\
Kadar Lemak (\%) & 5,70 & 3,78 \\
\hline
\end{tabular}

Hasil analisa bahan baku menunjukan bahwa ikan lele dumbo pada penelitian ini memiliki kadar $\mathrm{NaCl}$ dan Abu Tidak Larut Asam sebesar 0\% hal ini disebabkan ikan lele berasal dari jenis air tawar sehingga tidak ada 
komponen $\mathrm{NaCl}$ didalamnya, selain itu tidak adanya kadar abu tidak larut asam (cemaran mineral eksternal) didalamnya disebabkan karena budidaya ikan lele tersebut menggunakan media terpal sehingga residu tanah dan pasir dalam ikan dapat dihindari. Pada analisa kadar air menunjukan ikan lele memiliki presentase sebesar 74,90\%, Total Plate Count 3,07 x 105, Kadar Protein 13,17\%, Kadar Lemak 3,78 \%.

\section{Karakteristik Ikan Asin}

\section{Kadar $\mathrm{NaCl}$}

Berdasarkan hasil analisis ragam menunjukan bahwa terjadi interaksi sangat nyata $(\mathrm{P}<0,01)$ antara penggunaan metode Salting dan konsentrasi $\mathrm{NaCl}$ yang berbeda terhadap kadar $\mathrm{NaCl}$ pada produk ikan lele asin kering yang dihasilkan, adanya perbedaan yang sangat nyata ini disebabkan karena $\mathrm{NaCl}$ memiliki tekanan osmotik yang tinggi, sehingga terjadi proses dehidrasi osmosis pada ikan yang berakibat pada naiknya kadar $\mathrm{NaCl}$ seiring dengan tingginya konsentrasi $\mathrm{NaCl}$ yang diberikan. Rata-rata kadar $\mathrm{NaCl}$ dapat dilihat pada Tabel 2.

Tabel 2. Rata-rata Kadar NaCl Ikan Lele Asin Kering dengan Metode Salting dan Konsentrasi $\mathrm{NaCl}$ yang Berbeda

\begin{tabular}{lc}
\hline Perlakuan & Konsentrasi NaCl (\%) \\
\hline Z1M1 (Dry Salting: NaCl 15\%) & $9,03^{\mathrm{abc}}$ \\
Z1M2 (Dry Salting $: \mathrm{NaCl} 25 \%)$ & $10,72^{\mathrm{bc}}$ \\
Z1M3 (Dry Salting: $\mathrm{NaCl} 35 \%)$ & $12,66^{\mathrm{cd}}$ \\
Z1M4 (Dry Salting $: \mathrm{NaCl} 45 \%)$ & $15,44^{\mathrm{d}}$ \\
Z2M1 (Wet Salting: $\mathrm{NaCl} 15 \%)$ & $6,54^{\mathrm{a}}$ \\
Z2M2 (Wet Salting: $\mathrm{NaCl} 25 \%)$ & $7,69^{\mathrm{ab}}$ \\
Z2M3 (Wet Salting: $\mathrm{NaCl} 35 \%)$ & $10,24^{\mathrm{abc}}$ \\
Z2M4 (Wet Salting: $\mathrm{NaCl} 45 \%)$ & $12,97^{\mathrm{cd}}$ \\
\hline
\end{tabular}

Nilai rata-rata yang diikuti oleh huruf yang sama menunjukkan tidak berbeda nyata dengan uji DMRT 5\%.

Berdasarkan pada tabel 2. Menunjukan bahwa rata-rata kadar $\mathrm{NaCl}$ berkisar antara 6,54-15,44\%, dengan nilai terendah pada perlakuan wet salting dengan konsentrasi $\mathrm{NaCl} 15 \%$ sebesar $6,54 \%$, sedangkan yang tertinggi pada perlakuan Dry Salting dengan konsentrasi $\mathrm{NaCl} 45 \%$ yakni $15,44 \%$. Penggunaan metode Dry Salting menghasilkan presentase $\mathrm{NaCl}$ yang cenderung lebih tinggi dibandingkan dengan metode Wet Salting. Hal ini disebabkan karena metode dry salting memiliki (driving force) $\mathrm{NaCl}$ yang lebih tinggi sebagai akibat dari adanya penambahan air pada metode wet salting, perbedaan driving force ini berakibat pada perbedaan kecepatan penetrasi $\mathrm{NaCl}$ ke jaringan ikan, sehingga sangat mempengaruhi peningkatan kadar NaCl. Menurut Medina (2002) Hal ini 
berkaitan dengan driving force awal proses dehidrasi osmosis, semakin besar konsentrasi awal larutan yang digunakan maka semakin besar perbedaan konsentrasi (driving force) antara di dalam ikan dan di larutan osmosis.

\section{Kadar Air}

Berdasarkan hasil analisis ragam menunjukan bahwa terjadi interaksi sangat nyata $(\mathrm{P}<0,01)$ pada penggunaan perbedaan jenis metode salting dan konsentrasi $\mathrm{NaCl}$ yang berbeda. Namun secara terpisah penggunaan jenis salting memberi pengaruh nyata $(\mathrm{P}<0,05)$. Sedangkan penggunaan berbagai konsentrasi $\mathrm{NaCl}$ memberi pengaruh sangat nyata $(\mathrm{P}<0,01)$ terhadap kadar air ikan lele asin kering yang dihasilkan. Rata-rata kadar $\mathrm{NaCl}$ dapat dilihat pada Tabel 3.

Tabel 3. Rata-rata Kadar Air Ikan Lele Asin Kering dengan Metode Salting dan Konsentrasi $\mathrm{NaCl}$ yang Berbeda

\begin{tabular}{ll}
\hline Perlakuan & Kadar Air (\%) \\
\hline Z1M1 (Dry Salting: $\mathrm{NaCl} 15 \%)$ & $25,07^{\mathrm{de}}$ \\
Z1M2 (Dry Salting: $\mathrm{NaCl} 25 \%)$ & $22,96^{\mathrm{cde}}$ \\
Z1M3 (Dry Salting: $\mathrm{NaCl} 35 \%)$ & $19,47^{\mathrm{ab}}$ \\
Z1M4 (Dry Salting: $\mathrm{NaCl} 45 \%)$ & $16,67^{\mathrm{a}}$ \\
Z2M1 (Wet Salting: $\mathrm{NaCl} 15 \%)$ & $28,80^{\mathrm{f}}$ \\
Z2M2 (Wet Salting: $\mathrm{NaCl} 25 \%)$ & $25,31^{\mathrm{ef}}$ \\
Z2M3 (Wet Salting: $\mathrm{NaCl} 35 \%)$ & $22,10^{\mathrm{bcd}}$ \\
Z2M4 (Wet Salting: $\mathrm{NaCl} 45 \%)$ & $20,23^{\mathrm{bc}}$ \\
\hline
\end{tabular}

Nilai rata-rata yang diikuti oleh huruf yang sama menunjukkan tidak berbeda nyata dengan uji DMRT 5\%.

Berdasarkan hasil pada Tabel 3. menunjukan rata-rata kadar Air berkisar antara 16,67-28,80\%, dimana terjadi kecenderungan penurunan kadar air seiring dengan bertambahnya konsentrasi $\mathrm{NaCl}$ yang digunakan. Dengan nilai terendah pada perlakuan Dry salting dengan konsentrasi $\mathrm{NaCl} 45 \%$ sebesar 16,67\%, sedangkan nilai tertinggi pada perlakuan Wet Salting dengan konsentrasi $\mathrm{NaCl}$ 15\% yakni 28,80\%. Artinya dari semua perlakuan sampel kadar Air masih memenuhi SNI No. 8273-2016, karena masih dibawah batas maksimum 40\%. Penurunan kadar air ini disebabkan karena pada saat penggaraman berlangsung terjadi penetrasi $\mathrm{NaCl}$ kedalam jaringan ikan, yang berakibat keluarnya cairan pada tubuh ikan, hal ini terjadi karena air akan bergerak dari konsentrasi garam rendah ke konsentrasi garam tinggi karena adanya perbedaan tekanan osmosis. Menurut Rahman, (2007) dalam Witono dkk (2013). dehidrasi osmosis terjadi karena adanya gaya pendorong berupa perbedaan konsentrasi antara larutan dan di dalam sel. Air akan keluar dari dalam sel, sedangkan solut dari larutan masuk ke dalam cairan sel. Transfer air 
terjadi melalui proses difusi dan kapilaritas, sedangkan transfer zat terlarut hanya terjadi melalui proses difusi.

\section{Kadar Abu Tidak Larut Asam}

Berdasarkan hasil analisis ragam menunjukan bahwa terjadi interaksi nyata $(\mathrm{P}<0,05)$ pada penggunaan perbedaan jenis metode salting dan konsentrasi $\mathrm{NaCl}$. Namun secara terpisah penggunaan jenis metode salting dan konsentrasi $\mathrm{NaCl}$ yang berbeda berpengaruh sangat nyata $(\mathrm{P}<0,01)$ terhadap kadar Abu Tidak Larut Asam pada produk ikan lele asin kering yang dihasilkan. Rata-rata kadar Abu Tidak Larut Asam dapat dilihat pada Tabel 4.

Tabel 4. Rata-rata Kadar Abu Tidak Larut Asam Ikan Lele Asin Kering dengan Metode Salting dan Konsentrasi $\mathrm{NaCl}$ yang Berbeda

\begin{tabular}{ll}
\hline Perlakuan & Kadar Abu Tidak Larut Asam (\%) \\
\hline Z1M1 (Dry Salting: $\mathrm{NaCl} 15 \%)$ & $0,09^{\mathrm{b}}$ \\
Z1M2 (Dry Salting: $\mathrm{NaCl} 25 \%)$ & $0,11^{\mathrm{bc}}$ \\
Z1M3 (Dry Salting: $\mathrm{NaCl} 35 \%)$ & $0,14^{\mathrm{cd}}$ \\
Z1M4 (Dry Salting: $\mathrm{NaCl} 45 \%)$ & $0,21^{\mathrm{e}}$ \\
Z2M1 (Wet Salting: $\mathrm{NaCl} 15 \%)$ & $0,05^{\mathrm{a}}$ \\
Z2M2 (Wet Salting: $\mathrm{NaCl} 25 \%)$ & $0,08^{\mathrm{ab}}$ \\
Z2M3 (Wet Salting: $\mathrm{NaCl} 35 \%)$ & $0,12^{\mathrm{bcd}}$ \\
Z2M4 (Wet Salting: $\mathrm{NaCl} 45 \%)$ & $0,16^{\mathrm{d}}$ \\
\hline
\end{tabular}

Nilai rata-rata yang diikuti oleh huruf yang sama menunjukkan tidak berbeda nyata dengan uji DMRT $5 \%$.

Berdasarkan hasil pada Tabel 4. menunjukan rata-rata kadar abu tidak larut asam berkisar antara 0,05-0,21\%, dimana terjadi kecenderungan kenaikan kadar abu tidak larut asam seiring dengan bertambahnya konsentrasi $\mathrm{NaCl}$ yang digunakan. Dengan nilai terendah pada perlakuan Wet salting dengan konsentrasi $\mathrm{NaCl} 15 \%$ sebesar $0,05 \%$, sedangkan nilai tertinggi pada perlakuan Dry Salting dengan konsentrasi $\mathrm{NaCl} 45 \%$ yakni 0,21\%. dengan hasil ini bisa disimpulkan bahwa dari semua perlakuan sampel masih memenuhi SNI No. 8273-2016, karena masih dibawah batas maksimum 0,3\%. Adanya kadar abu tidak larut asam dalam produk ikan asin kering ini mengindikasikan bahwasannya $\mathrm{NaCl}$ yang digunakan masih ada cemaran mineral eksternal atau bahan-bahan silica, pasir dan tanah.

Pada hasil ini juga menunjukan bahwa rata-rata kadar abu tidak larut asam ikan lele asin kering dengan penggunaan metode Dry Salting menghasilkan presentase mineral eksternal yang cenderung lebih tinggi dibandingkan dengan metode Wet Salting. Hal ini diduga disebabkan karena metode Dry salting dilakukan dengan proses penaburan secara langsung, sehingga mineral eksternal yang dibawa oleh $\mathrm{NaCl}$ menempel pada dinding ikan 
pada saat penggaraman berlangsung. Sedangkan wet salting memiliki presentase yang lebih rendah hal ini diduga disebabkan karena penggunaan metode ini dengan penambahan air sehingga mineral eksternal yang dibawa oleh $\mathrm{NaCl}$ ikut larut dalam air. Selain itu adanya komponen abu tidak larut asam ini bisa juga dipengaruhi oleh kondisi bahan baku. Menurut, Witono, dkk. (2013) Hal ini kemungkinan karena kandungan mineral dan logam pada ikan tidak hanya berasal dari proses dehidrasi osmosis yang dilakukan, tetapi juga dipengaruhi oleh kondisi bahan baku ikan segar.

\section{Total Plate Count}

Berdasarkan hasil analisis ragam menunjukan bahwa terjadi interaksi nyata $(\mathrm{P}<0,05)$ pada penggunaan jenis metode salting dan konsentrasi $\mathrm{NaCl}$. Namun secara terpisah penggunaan jenis metode salting dan konsentrasi $\mathrm{NaCl}$ yang berbeda berpengaruh sangat nyata $(\mathrm{P}<0,01)$ terhadap Total Plate Count pada produk ikan lele asin kering yang dihasilkan. Rata-rata Total Plate Count dapat dilihat pada Tabel 5.

Tabel 5. Rata-rata Total Plate Count Ikan Lele Asin Kering dengan Metode Salting dan Konsentrasi NaCl yang Berbeda

\begin{tabular}{|c|c|}
\hline Perlakuan & $\begin{array}{l}\text { Total Plate Count } \\
\text { (Koloni/gram) }\end{array}$ \\
\hline Z1M1 (Dry Salting: NaCl 15\%) & $2,6 \times 10^{4} \mathrm{de}$ \\
\hline Z1M2 (Dry Salting: $\mathrm{NaCl} 25 \%)$ & $2,2 \times 10^{4} \mathrm{~cd}$ \\
\hline Z1M3 (Dry Salting: NaCl 35\%) & $1,6 \times 10^{4} \mathrm{ab}$ \\
\hline Z1M4 (Dry Salting: $\mathrm{NaCl} 45 \%$ ) & $1,1 \times 10^{4} \mathrm{a}$ \\
\hline Z2M1 (Wet Salting: $\mathrm{NaCl} 15 \%$ ) & $3,0 \times 10^{4} \mathrm{e}$ \\
\hline Z2M2 (Wet Salting: NaCl 25\%) & $2,7 \times 10^{4} \mathrm{de}$ \\
\hline Z2M3 (Wet Salting: $\mathrm{NaCl} 35 \%$ ) & $2,1 \times 10^{4} \mathrm{bcd}$ \\
\hline Z2M4 (Wet Salting: $\mathrm{NaCl} 45 \%$ ) & $1,7 \times 10^{4} \mathrm{abc}$ \\
\hline
\end{tabular}

Nilai rata-rata yang diikuti oleh huruf yang sama menunjukkan tidak berbeda nyata dengan uji DMRT 5\%.

Hasil pada Tabel 5. menunjukan rata-rata Total Plate Count berkisar antara $1,1 \times 10^{4-3,0} \times 10^{4} \mathrm{koloni} / \mathrm{ml}$. Dimana terjadi kecenderungan penurunan total koloni seiring dengan bertambahnya konsentrasi $\mathrm{NaCl}$ yang digunakan. Dengan nilai terendah pada perlakuan Dry salting dengan konsentrasi $\mathrm{NaCl}$ $45 \%$ sebesar $1,1 \times 10^{4} \mathrm{koloni} / \mathrm{ml}$, sedangkan nilai tertinggi pada perlakuan Wet Salting dengan konsentrasi $\mathrm{NaCl} 15 \%$ yakni 3,0 x $10^{4} \mathrm{koloni} / \mathrm{ml}$. Hasil ini menunjukan bahwa dari semua perlakuan sampel masih memenuhi SNI No. 8273-2016, karena masih dibawah batas maksimum 1 x $10^{5} \mathrm{koloni} / \mathrm{ml}$. Penurunan total koloni ini diduga karena $\mathrm{NaCl}$ yang terlarut dalam jaringan ikan menyebabkan tekanan osmotik yang lebih tinggi dari pada tekanan osmotik di dalam sel bakteri, yang berakibat pada berkurangnya air dalam jaringan ikan, 
sehingga terjadi kematian sel mikroba karena $\mathrm{NaCl}$ bersifat higroskopik, selain itu adanya garam dalam daging ikan juga dapat mengurangi jumlah oksigen, sehingga dapat menghambat pertumbuhan mikroba aerobik. Menurut Hudaya dan Daradjat (1982) dalam Putriana (2014) Garam dapat menyerap air dan mengurangi kelarutan oksigen pada bahan yang dibutuhkan untuk pertumbuhan bakteri.

Pada hasil ini juga menunjukan bahwa rata-rata total plate count ikan lele asin kering dengan penggunaan metode Dry Salting menghasilkan total koloni yang cenderung lebih rendah dibandingkan dengan metode Wet Salting. Hal ini diduga disebabkan karena metode Dry salting dilakukan dengan proses penaburan secara langsung sehingga $\mathrm{NaCl}$ lebih mudah masuk dalam jaringan ikan, sedangkan wet salting dengan penambahan air sehingga penetrasi garam dalam tubuh ikan berjalan lebih lambat. Jumlah koloni dalam bahan pangan sangat erat kaitannya dengan kadar air yang ada pada bahan pangan, semakin tinggi kadar air maka semakin tinggi pula total koloni pada bahan pangan, begitupun sebaliknya semakin rendah kadar air maka semakin rendah pula total koloni dalam bahan pangan tersebut. Menurut, Marpaung (2015). kadar air bahan pangan mempunyai kaitan erat dengan keawetan bahan pangan. Bahan pangan yang berkadar air rendah akan lebih awet dibandingkan yang berkadar air tinggi . Hal ini terjadi karena dalam proses enzimatis dan kimiawi serta pertumbuhan bakteri diperlukan sejumlah air. Turunnya kadar air yang ada dalam suatu bahan akan mencegah pertumbuhan bakteri dan kebusukan bahan pangan tersebut.

\section{Kadar Protein}

Berdasarkan hasil analisis ragam menunjukan bahwa tidak terjadi interaksi nyata $(\mathrm{P}>0,05)$ antara penggunaan perbedaan jenis metode salting dan konsentrasi $\mathrm{NaCl}$. Namun secara terpisah penggunaan konsentrasi $\mathrm{NaCl}$ yang berbeda berpengaruh sangat nyata $(\mathrm{P}<0,01)$ terhadap kadar protein ikan lele asin kering yang dihasilkan. Rerata kadar protein akibat penggunaan konsentrasi $\mathrm{NaCl}$ yang berbeda dapat dilihat pada Tabel 6 .

Tabel 6. Rerata Kadar Protein Ikan Lele Asin Kering dengan Konsentrasi NaCl yang Berbeda

\begin{tabular}{ll}
\hline Perlakuan & Kadar Protein (\%) \\
\hline NaCl Konsentrasi 15\% & $13,46^{\mathrm{a}}$ \\
$\mathrm{NaCl}$ Konsentrasi $25 \%$ & $14,65^{\mathrm{a}}$ \\
$\mathrm{NaCl}$ Konsentrasi $35 \%$ & $16,35^{\mathrm{ab}}$ \\
$\mathrm{NaCl}$ Konsentrasi $45 \%$ & $18,14^{\mathrm{b}}$ \\
\hline
\end{tabular}

Nilai rata-rata yang diikuti oleh huruf yang sama menunjukkan tidak berbeda nyata dengan uji DMRT $5 \%$. 
Hasil pada Tabel 6. menunjukan rerata Kadar Protein berkisar antara 13,46-18,14\%. terjadi kecenderungan kenaikan kadar protein seiring dengan bertambahnya konsentrasi $\mathrm{NaCl}$ yang digunakan, dengan nilai terendah pada perlakuan Wet Salting dengan konsentrasi $\mathrm{NaCl}$ 15\% sebesar 13,46\%, sedangkan nilai tertinggi pada perlakuan Dry Salting dengan konsentrasi $\mathrm{NaCl} 45 \%$ yakni 18,14\%. Hal ini diduga karena pada konsentrasi $\mathrm{NaCl}$ yang rendah terjadi reaksi Salting In yang mengakibatkan protein menjadi bermuatan dan larut dalam larutan $\mathrm{NaCl}$ sehingga presentase protein menurun. Proses Kelarutan protein akan terus meningkat sejalan dengan peningkatan konsentrasi $\mathrm{NaCl}$, apabila konsentrasi $\mathrm{NaCl}$ ditingkatkan maka terjadi reaksi Salting Out kelarutan protein akan turun, yang mengakibatkan pengendapan protein, pengendapan ini terjadi karena proses persaingan antara garam dan protein untuk mengikat air sehingga presentase protein meningkat, hal ini disebabkan karena ion $\mathrm{NaCl}$ memiliki densitas muatan yang lebih besar dibandingkan protein. Menurut literatur Hanry and Steinberg (1984) dalam Rahmani (2007) $\mathrm{NaCl}$ dapat berinteraksi dengan protein, pada konsentrasi $\mathrm{NaCl}$ rendah menyebabkan protein mengalami salting in (protein turun) dan pada konsentrasi $\mathrm{NaCl}$ tinggi protein mengalami salting out (protein naik). Pada proses salting in protein akan lebih mudah larut, sebaliknya pada peristiwa salting out protein akan mengendap dan tidak mudah larut.

Tabel 7. Rerata Kadar Protein Ikan Lele Asin Kering dengan Metode Salting yang Berdeda

\begin{tabular}{ll}
\hline Perlakuan & Kadar Protein (\%) \\
\hline Dry Salting & $16,47^{\mathrm{b}}$ \\
Wet Salting & $14,82^{\mathrm{a}}$ \\
\hline
\end{tabular}

Nilai rata-rata yang diikuti oleh huruf yang sama menunjukkan tidak berbeda nyata dengan uji DMRT 5\%.

Berdasarkan pada Tabel 7. menunjukan bahwa nilai Rerata kadar Protein ikan lele asin kering dengan penggunaan metode Dry Salting menghasilkan presentase kadar protein yang cenderung lebih tinggi dibandingkan dengan metode Wet Salting. Hal ini disebabkan karena metode dry salting memiliki (driving force) $\mathrm{NaCl}$ yang lebih tinggi dibanding dengan metode wet salting sebagai akibat dari adanya penambahan air pada metode wet salting, perbedaan driving force ini berakibat pada perbedaan kecepatan penetrasi $\mathrm{NaCl}$ ke jaringan ikan, sehingga semakin tinggi penggunaan konsentrasi $\mathrm{NaCl}$ sangat mempengaruhi penurunan kadar air. Kenaikan kadar protein ini sangat erat kaitannya dengan kadar air yang ada pada bahan, semakin rendah kadar air maka kadar proteinnya juga semakin tinggi. Menurut Reo (2013), Peningkatan jumlah kadar protein pada bahan ikan asin disebabkan oleh rendahnya kadar air sehingga kadar protein meningkat, semakin tinggi konsentrasi $\mathrm{NaCl}$ dan 
lama pengeringan, maka kadar $\mathrm{NaCl}$ yang terserap kedalam daging ikan semakin tinggi, sedangkan kadar air semakin menurun mengakibatkan meningkatnya kandungan protein. Hal ini disebabkan oleh garam yang diserap ke dalam daging mendenaturasi protein sehingga terjadi terkoagulasi yang membebaskan air keluar dari daging ikan.

\section{Kadar Lemak}

Berdasarkan hasil analisis ragam pada (Lampiran 6) menunjukan bahwa tidak terjadi interaksi nyata $(\mathrm{P}>0,05)$ pada penggunaan perbedaan jenis metode salting dan konsentrasi $\mathrm{NaCl}$ yang berbeda, dan dari semua perlakuan tidak berpengaruh nyata $(\mathrm{P}>0,05)$ pada kadar lemak ikan lele asin kering yang dihasilkan. Rerata penggunaan metode salting dan konsentrasi $\mathrm{NaCl}$ yang berbeda pada kadar lemak ikan lele asin kering dapat dilihat pada Gambar 1.

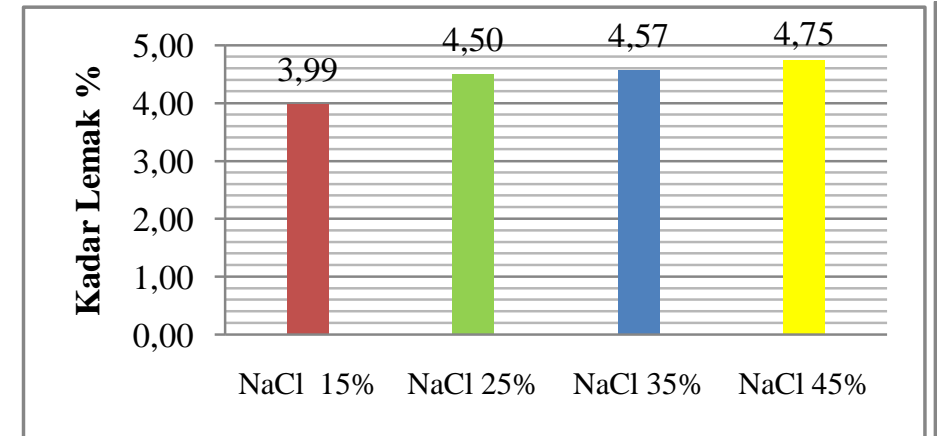

(a)

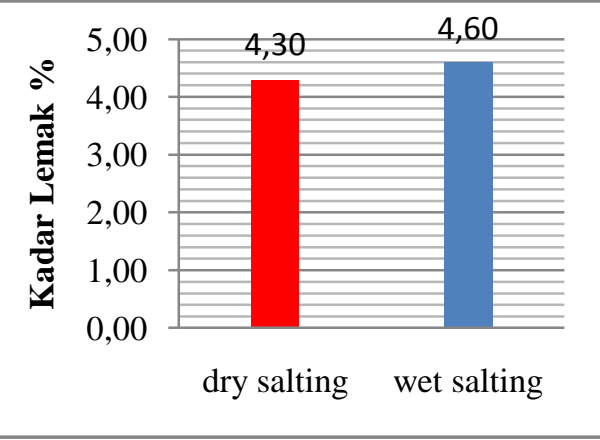

(b.)

Gambar 1. Rerata Kadar Lemak pada Konsentrasi $\mathrm{NaCl}$ (a.) dan Metode Salting (b.)

Hasil pada Gambar 1. menunjukan rerata Kadar lemak pada penggunaan metode salting dan konsentrasi $\mathrm{NaCl}$ yang berbeda tidak memberikan perbedaan nyata dengan rerata terendah pada konsentrasi $\mathrm{NaCl} 15 \%$ sebesar 3,99\%, sedangkan rerata tertinggi pada konsentrasi $\mathrm{NaCl} 45 \%$ yakni $4,75 \%$.. Hal ini diduga dikarenakan proses penggaraman dan penggeringan dengan waktu dan suhu yang sama sehingga tidak ada perbedaan hasil yang nyata antar perlakuan, selain itu hasil ini juga diduga karena jenis ikan dan umur yang digunakan sama.

\section{Organoleptik}

Rasa

Berdasarkan hasil analisis menggunakan Kruskal Wallis pada parameter organoleptik rasa menunjukan nilai Asymp. Sig 0,010<0,05 yang berarti menerima $\mathrm{H} 1$ atau perlakuan memberikan pengaruh yang bermakna terhadap rasa, untuk mengetahui perbedaan antar perlakuan dilanjutkan pada Uji Mann Whitney. Hasil pada uji mann whitney menunjukan pengaruh yang berbeda- 
beda antar perlakuan, jika nilai Sig atau $\mathrm{P}$ value $<0,05$ maka terdapat perbedaan bermakna antara dua kelompok atau yang berarti $\mathrm{H} 1$ diterima. Hasil uji kruskal wallis dan mann whitney ikan lele asin kering dapat dilihat pada Tabel 8.

Tabel 8. Hasil Analisis Kruskal Wallis dan Mann Whitney Pada Organoletik Rasa

\begin{tabular}{lccl}
\hline Perlakuan & $\mathrm{N}$ & Mean Rank & Skor \\
\hline Z1M1 (Dry Salting: $: \mathrm{NaCl} 15 \%)$ & 3 & 21,00 & $7,67^{\mathrm{a}}$ \\
Z1M2 (Dry Salting: $\mathrm{NaCl} 25 \%)$ & 3 & 11,67 & $5,42^{\mathrm{ab}}$ \\
Z1M3 (Dry Salting: $: \mathrm{NaCl} 35 \%)$ & 3 & 7,67 & $5,17^{\mathrm{abc}}$ \\
Z1M4 (Dry Salting $: \mathrm{NaCl} 45 \%)$ & 3 & 4,00 & $5,00^{\mathrm{bd}}$ \\
Z2M1 (Wet Salting $: \mathrm{NaCl} 15 \%)$ & 3 & 22,00 & $8,08^{\mathrm{ace}}$ \\
Z2M2 (Wet Salting $: \mathrm{NaCl} 25 \%)$ & 3 & 15,67 & $5,67^{\mathrm{abcf}}$ \\
Z2M3 (Wet Salting $: \mathrm{NaCl} 35 \%)$ & 3 & 10,33 & $5,33^{\mathrm{bdfg}}$ \\
Z2M4 (Wet Salting $: \mathrm{NaCl} 45 \%)$ & 3 & 7,67 & $5,17^{\mathrm{abdefg}}$ \\
\hline
\end{tabular}

Nilai rata-rata yang diikuti oleh huruf yang sama menunjukkan tidak berbeda nyata dengan uji DMRT $5 \%$.

Skor Rasa : $\quad 5=$ Asin, spesifik jenis

$7=$ Asin, spesifik jenis kurang

$9=$ Asin, ada rasa tambahan

Hasil pada Tabel 8. menunjukan nilai rata-rata penerimaan panelis berkisar antara 5-8,08. terjadi kecenderungan penurunan penerimaan rasa seiring dengan bertambahnya konsentrasi $\mathrm{NaCl}$ yang digunakan. Dengan nilai terendah pada perlakuan Dry Salting dengan konsentrasi $\mathrm{NaCl} 45 \%$ dengan skor 5, sedangkan nilai tertinggi pada perlakuan Wet Salting dengan konsentrasi $\mathrm{NaCl}$ 15\% dengan skor 8.08. Hal ini disebabkan semakin tinggi penggunaan konsentrasi $\mathrm{NaCl}$ maka rasa yang dihasilkan juga semakin asin, sedangkan secara umum panelis lebih menyukai produk ikan asin dengan tingkat keasinan yang rendah. Hal ini sejalan dengan penelitian Roberto dkk. (2013), semakin tinggi konsentrasi garam, semakin rendah pula nilai penerimaan panelis terhadap rasa. Konsentrasi garam yang tinggi menyebabkan tingkat keasinan ikan asin semakin tinggi.

\section{Kenampakan}

Berdasarkan hasil analisis menggunakan Kruskal Wallis pada parameter organoleptik kenampakan menunjukan nilai Asymp. Sig 0,111>0,05. Yang berarti H0 diterima, Jika H0 diterima maka setiap perlakuan sama. sehingga bisa disimpulkan bahwa penggunaan perbedaan jenis metode salting dan konsentrasi $\mathrm{NaCl}$ yang berbeda tidak berbeda nyata antar perlakuan pada organoleptik kenampakan ikan lele asin kering. Hasil uji kruskal wallis pada organoleptik kenampakan ikan lele asin kering dapat dilihat pada Tabel 9. 
Tabel 9. Hasil Analisis Kruskal Wallis Pada Organoletik Kenampakan

\begin{tabular}{|c|c|c|c|}
\hline Perlakuan & $\mathrm{N}$ & Mean Rank & Skor \\
\hline Z1M1 (Dry Salting: NaCl 15\%) & 3 & 21,33 & $8,08^{\mathrm{a}}$ \\
\hline Z1M2 (Dry Salting: $\mathrm{NaCl} 25 \%)$ & 3 & 17,67 & $7,50^{\mathrm{a}}$ \\
\hline Z1M3 (Dry Salting: $\mathrm{NaCl} 35 \%)$ & 3 & 11,00 & $7,17^{\mathrm{a}}$ \\
\hline Z1M4 (Dry Salting: $\mathrm{NaCl} 45 \%)$ & 3 & 8,67 & $7,08^{\mathrm{a}}$ \\
\hline Z2M1 (Wet Salting: $\mathrm{NaCl} 15 \%)$ & 3 & 5,33 & $6,75^{\mathrm{a}}$ \\
\hline Z2M2 (Wet Salting: $\mathrm{NaCl} 25 \%)$ & 3 & 11,67 & $7,25^{\mathrm{a}}$ \\
\hline Z2M3 (Wet Salting: $\mathrm{NaCl} 35 \%)$ & 3 & 9,33 & $7,17^{\mathrm{a}}$ \\
\hline Z2M4 (Wet Salting: $\mathrm{NaCl} 45 \%)$ & 3 & 15,00 & $7,58^{\mathrm{a}}$ \\
\hline \multicolumn{4}{|c|}{$\begin{array}{l}\text { Nilai rata-rata yang diikuti oleh huruf yang sama menunjukkan tidak berbeda nyata dengan u } \\
\text { DMRT } 5 \% \text {. }\end{array}$} \\
\hline Skor kenampakan: & & & \\
\hline
\end{tabular}

Hasil pada Tabel 9. menunjukan nilai mean rank organoleptik Kenampakan berkisar pada rentang 5,33-21,33, secara hitungan statistik penggunaan metode salting dan konsentrasi $\mathrm{NaCl}$ yang berbeda tidak memberikan perbedaan yang nyata. Dari semua perlakuan Kenampakan ikan terlihat sama dan tidak terdapat kerusakan fisik serta tidak adanya perubahan warna yang berarti. Namun, terjadi kecenderungan penurunan nilai kenampakan pada dry salting seiring dengan bertambahnya konsentrasi $\mathrm{NaCl}$ yang digunakan pada kisaran 7.08-8.08. Hal ini diduga disebabkan karena semakin tinggi Konsentrasi $\mathrm{NaCl}$ yang digunakan berdampak pada kenampakan ikan asin kering sehingga ikan akan berubah menjadi putih karena Kristal $\mathrm{NaCl}$ menempel pada permukaan daging ikan. Namun, penggunaan metode wet salting menunjukan kecenderungan peningkatan nilai rata-rata seiring dengan meningkatnya konsentrasi $\mathrm{NaCl}$ pada rentang 6,75-7,58, hal ini disebabkan karena proses salting pada metode ini menggunakan media air sehingga kenampakannya lebih bersih dan tidak ada Kristal $\mathrm{NaCl}$ yang menempel pada permukaan daging ikan lele asin kering yang berakibat pada tingginya penerimaan panelis. Menurut Roberto dkk. (2013), konsentrasi garam dan lama penggaraman yang semakin tinggi, membuat penerimaan panelis cenderung semakin menurun. Konsentrasi garam dan lama penggaraman yang semakin tinggi menyebabkan kenampakan ikan asin kering terlihat lebih putih karena kristal garam yang terdapat pada permukaan tubuh ikan sehingga tingkat kesukaan panelis berkurang.

\section{Aroma}

Berdasarkan hasil analisis menggunakan Kruskal Wallis pada parameter organoleptik aroma menunjukan nilai Asymp. Sig 0,769>0,05. Yang berarti H0 diterima, Jika H0 diterima maka setiap perlakuan sama. sehingga bisa 
disimpulkan bahwa penggunaan perbedaan jenis metode salting dan konsentrasi $\mathrm{NaCl}$ yang berbeda tidak berbeda nyata antar perlakuan pada organoleptik aroma ikan lele asin kering. Hasil uji kruskal wallis pada organoleptik kenampakan ikan lele asin kering dapat dilihat pada Tabel 10.

Tabel 10. Hasil Analisis Kruskal Wallis Pada Organoletik Aroma

\begin{tabular}{lccc}
\hline Perlakuan & $\mathrm{N}$ & Mean Rank & Skor \\
\hline Z1M1 (Dry Salting: $\mathrm{NaCl} 15 \%)$ & 3 & 16,00 & $7,67 \mathrm{a}$ \\
Z1M2 (Dry Salting: $\mathrm{NaCl} 25 \%)$ & 3 & 16,00 & $7,71^{\mathrm{a}}$ \\
Z1M3 (Dry Salting $: \mathrm{NaCl} 35 \%)$ & 3 & 9,17 & $7,25^{\mathrm{a}}$ \\
Z1M4 (Dry Salting: $: \mathrm{NaCl} 45 \%)$ & 3 & 7,33 & $6,92^{\mathrm{a}}$ \\
\hline Z2M1 (Wet Salting $: \mathrm{NaCl} 15 \%)$ & 3 & 14,00 & $7,58^{\mathrm{a}}$ \\
Z2M2 (Wet Salting $: \mathrm{NaCl}$ 25\%) & 3 & 12,83 & $7,42^{\mathrm{a}}$ \\
Z2M3 (Wet Salting $: \mathrm{NaCl} 35 \%)$ & 3 & 11,33 & $7,33^{\mathrm{a}}$ \\
Z2M4 (Wet Salting $: \mathrm{NaCl} 45 \%)$ & 3 & 13,33 & $7,50^{\mathrm{a}}$ \\
\hline
\end{tabular}

Nilai rata-rata yang diikuti oleh huruf yang sama menunjukkan tidak berbeda nyata dengan uji DMRT 5\%.

Skor Aroma : $5=$ Tengik, apak

$7=$ Spesifik jenis kurang kuat

$9=$ Spesifik jenis kuat

Hasil pada Tabel 10. menunjukan nilai mean rank organoleptik aroma berkisar pada rentang 7,33-16,00, secara hitungan statistik penggunaan metode salting dan konsentrasi $\mathrm{NaCl}$ yang berbeda tidak memberikan perbedaan yang nyata. semua perlakuan Aroma terlihat sama. Hal ini karena tidak adanya proses penyimpanan dan saat pengujian menggunakan ikan asin kering yang baru diproduksi, sehingga belum terjadi penyimpangan yang diakibatkan oksidasi lemak. Menurut Rahayu, dkk. (1992) dalam Rochima (2005), meskipun oksidasi lemak dapat mengakibatkan ketengikan (rancidity), namun apabila prosesnya belum berlanjut, maka akan menghasilkan aroma yang justru disukai oleh konsumen.

\section{Tekstur}

Berdasarkan hasil analisis menggunakan Kruskal Wallis pada parameter organoleptik Tekstur menunjukan nilai Asymp. Sig 0,228>0,05. Yang berarti H0 diterima, Jika H0 diterima maka setiap perlakuan sama. sehingga bisa disimpulkan bahwa penggunaan perbedaan jenis metode salting dan konsentrasi $\mathrm{NaCl}$ yang berbeda tidak berbeda nyata antar perlakuan pada organoleptik tekstur ikan lele asin kering. Hasil uji kruskal wallis pada organoleptik tekstur ikan lele asin kering dapat dilihat pada Tabel 11. 
Tabel 11. Hasil Analisis Kruskal Wallis Pada Organoletik Tekstur

\begin{tabular}{|c|c|c|c|}
\hline Perlakuan & $\mathrm{N}$ & Mean Rank & Skor \\
\hline Z1M1 (Dry Salting: $\mathrm{NaCl} 15 \%)$ & 3 & 9,17 & $6,50^{\mathrm{a}}$ \\
\hline Z1M2 (Dry Salting: $\mathrm{NaCl} 25 \%)$ & 3 & 12,00 & $7,00^{\mathrm{a}}$ \\
\hline Z1M3 (Dry Salting: NaCl 35\%) & 3 & 15,83 & $7,25^{\mathrm{a}}$ \\
\hline Z1M4 (Dry Salting: $\mathrm{NaCl} 45 \%)$ & 3 & 19,50 & $7,67^{\mathrm{a}}$ \\
\hline Z2M1 (Wet Salting: $\mathrm{NaCl} 15 \%)$ & 3 & 6,17 & $6,08^{\mathrm{a}}$ \\
\hline Z2M2 (Wet Salting: $\mathrm{NaCl} 25 \%)$ & 3 & 8,00 & $6,25^{\mathrm{a}}$ \\
\hline Z2M3 (Wet Salting: $\mathrm{NaCl} 35 \%)$ & 3 & 12,17 & $6,83^{\mathrm{a}}$ \\
\hline Z2M4 (Wet Salting: $\mathrm{NaCl} 45 \%)$ & 3 & 17,17 & $7,42^{\mathrm{a}}$ \\
\hline
\end{tabular}

Nilai rata-rata yang diikuti oleh huruf yang sama menunjukkan tidak berbeda nyata dengan uji DMRT 5\%.

Skor Tekstur : $5=$ Kurang padat, mulai rapuh $7=$ Padat, kurang kering $9=$ Padat, kering

Hasil pada Tabel 11. menunjukan nilai mean rank organoleptik tekstur berkisar pada rentang 6,17-19,50, secara hitungan statistik penggunaan metode salting dan konsentrasi $\mathrm{NaCl}$ yang berbeda tidak memberikan perbedaan yang nyata, semua perlakuan tekstur terlihat sama. dengan skor rata-rata berkisar antara 6,08-7,67. Hal ini disebabkan karena penerimaan panelis sangat erat kaitannya dengan kadar air yang ada pada bahan tersebut. Semakin tinggi konsentrasi $\mathrm{NaCl}$ maka tekstur dari ikan lebih padat dan kering sehingga disukai oleh panelis, menurut Rahmani, $d k k$. (2007) menyatakan bahwa nilai rata-rata kesukaan panelis terhadap tekstur ikan gabus asin terus meningkat seiring dengan meningkatnya konsentrasi garam dan lama perendaman, karena perlakuan tersebut menyebabkan ikan asin terlihat lebih kering karena kadar air yang rendah.

\section{Perlakuan Terbaik}

Penentuan perlakuan terbaik pada produk ikan lele asin kering dilakukan berdasarkan metode indeks efektivitas (NE) dan nilai poduk (NP) yang selanjutnya nilai produk pada setiap parameter dijumlah untuk mendapatkan perlakuan terbaik (De Garmo, 1998). Prinsip metode ini adalah membandingkan seluruh parameter yang diukur.

Hasil pengujian perlakuan terbaik terhadap berbagai parameter (Kadar $\mathrm{NaCl}$, Kadar Air, Kadar Abu Tidak Larut Asam, Total Plate Count, Kadar Protein, Kadar Lemak, dan uji Organoleptik) diperoleh total perhitungan perlakuan terbaik ke-1 (pertama) yaitu Z1M4 (Dry Salting : Konsentrasi $\mathrm{NaCl}$ 45\%) dan disusul oleh Z2M4 (Wet Salting: Konsentrasi NaCl 45\%) dapat dilihat pada Tabel 12 . 
Tabel 12. Total Perhitungan Perlakuan Terbaik Z1M4 (Dry Salting: Konsentrasi $\mathrm{NaCl} 45 \%$ ) dan Z2M4 (Wet Salting: Konsentrasi NaCl 45\%)

\begin{tabular}{|c|c|c|}
\hline \multirow{4}{*}{ Parameter } & \multicolumn{2}{|l|}{ Perlakuan Terbaik Ke- } \\
\hline & 1 & Perlakuan Terbaik Ke-2 \\
\hline & Z1M4 (Dry Salting: & Z2M4 (Wet Salting: \\
\hline & Konsentrasi $\mathrm{NaCl} 45 \%$ ) & Konsentrasi $\mathrm{NaCl}$ 45\%) \\
\hline kadar $\mathrm{NaCl}$ & 0,090 & 0,065 \\
\hline kadar air & 0,100 & 0,071 \\
\hline kadar atla & 0,000 & 0,025 \\
\hline Total plate count & 0,090 & 0,062 \\
\hline kadar protein & 0,070 & 0,050 \\
\hline kadar lemak & 0,019 & 0,000 \\
\hline Rasa & 0,000 & 0,005 \\
\hline Kenampkan & 0,015 & 0,037 \\
\hline Aroma & 0,000 & 0,044 \\
\hline Tekstur & 0,080 & 0,067 \\
\hline Total & 0,464 & 0,427 \\
\hline
\end{tabular}

Berdasarkan hasil uji perlakuan terbaik pada Tabel 12. Menunjukan Ikan lele asin kering dengan nilai paling tinggi terdapat pada perlakuan Z1M4 (Dry Salting: Konsentrasi NaCl 45\%) sebesar 0,464 dan nilai tertinggi kedua Z2M4 (Wet Salting: Konsentrasi $\mathrm{NaCl} 45 \%$ ) sebesar 0,427. Bobot normal terbesar dari nilai efektivitas terdapat pada parameter Kadar $\mathrm{NaCl}$, Kadar Air, Total Plate Count, Tekstur.

\section{KESIMPULAN}

Kesimpulan yang dapat diambil dalam penelitian ini adalah terjadinya interaksi antara penggunaan metode salting dan konsentrasi $\mathrm{NaCl}$ terhadap kadar $\mathrm{NaCl}$, kadar air, organoleptik rasa, kadar abu tidak larut asam, total plate count. Perlakuan penggunaan metode salting yang berbeda memberikan pengaruh pada parameter kadar $\mathrm{NaCl}$, kadar abu tidak larut asam, kadar protein, total plate count, kadar air, organoleptik rasa. Perlakuan penggunaan konsentrasi $\mathrm{NaCl}$ yang berbeda memberikan pengaruh terhadap kadar $\mathrm{NaCl}$, air, abu tidak larut asam, total plate count, protein. organoleptik rasa. Hasil penelitian menunjukkan bahwa total perlakuan terbaik pada Z1M4 (Dry Salting) dengan kadar $\mathrm{NaCl}$ 15,44\%, kadar air 16,67\%, kadar abu tidak larut asam $0,21 \%$, total plate count $1,1 \times 10^{4}$, kadar protein $25,27 \%$, kadar lemak 6,06\%, organoleptik (rasa) 5, organoleptik (kenampakan) 7,08, organoleptik (aroma) 6,92, organoleptik (tekstur) 7,67.

\section{REFERENSI}

Adawyah, R, 2011. Pengolahan dan pengawetan ikan. Edisi I, cetakan IV. Jakarta : Bumi aksara 
Dinas Kelautan dan Perikanan, 2016. Statistik hasil perikanan. Diakses 10 Mei 2017, dari dkp.jatimprov.go.id

Huss, H.H. 1994. Assurance aof Sea Food Quality. FAO Fisheries Technical Paper. Rome.

Marpaung, R. 2015. Kajian Mikrobiologi Pada Produk Ikan Asin Kering yang Dipasarkan Di Pasar Tradisional dan Pasar Swalayan Dalam Upaya Peningkatan Keamanan Pangan di Kota Jambi. Jambi. Jurnal Ilmiah vol15 No-3.Universitas Batanghari Jambi.

Medina-Vivanco, M., Sobral, P.J.do A., Hubinger, M.D. 2002. Osmotic dehydration of tilapia fillets in limited volume of ternary solutions. Chemical Engineering, 86, 199 - 205.

Rachmawan, O. 2001. Pengeringan, Pendinginan dan Pengemasan Komoditas Pertanian. Buletin Departemen Pendidikan Nasional. Jakarta.

Rahmani, Y. dan Erryana, M. 2007. Pengaruh Metode Penggaraman Basah Terhadap Karakteristik Produk Ikan Asin Gabus (Ophiocephalus striatus). Jurnal Teknologi Pertanian 8(3):142-152.

Reo, A.R. 2013. Mutu Ikan Kakap Merah yang Diolah Dengan Perbedaan Konsentrasi Larutan Garam dan Pengeringan. Bandung. Jurnal Perikanan dan Kelautan Tropis. Vol. IX-1. Universitas Sam Ratulangi.

Riansyah, A., Supriadi, A., Nopianti, R. 2013. Pengaruh Perbedaan Suhu dan Waktu Pengeringan Terhadap Karakteristik Ikan Asin Sepat Siam dengan Menggunakan Oven. Palembang. Fishtech vol-II. Universitas Sriwijaya.

Roberto, A. Tumbelaka, Asri S. Naiu, Faiza A. Dali. 2013. Pengaruh Konsentrasi Garam dan Lama Penggaraman Terhadap Nilai Hedonik Ikan Bandeng Asin Kering. Gorontalo. Jurnal Perikanan dan Kelautan. Vol-1 No-1. Universitas Negeri Gorontalo.

Rochima, E. 2005. Pengaruh Fermentasi Garam Terhadap Karakteristik Jambal Roti. Buletin Teknologi Hasil Perikanan. Vol : VIII No 2.

SNI 2721.1. 2009. Ikan Asin. Badan Standarisasi Nasional.

SNI 8273 : 2016, Ikan Asin Kering. ICS 67.120.30. Badan Standarisasi Nasional.

Sofiyanto. 2001. Penggunaan Berbagai Jenis Bahan Kemasan Dalam Mempertahankan Mutu Ikan Asin Patin (Pangasius hypophthalmus). Skripsi. Bogor (ID): Institut Pertanian Bogor.

Winarno, F. G. 1997. Kimia Pangan dan Gizi. Gramedia Pustaka Utama. Jakarta.

Witono, J.R.B., Miryanti, A., dan Yuniarti, L. 2013. Studi Kinetika Dehidrasi Osmotik Pada Ikan Teri Dalam Larutan Biner dan Terner. Bandung (ID): Lembaga Penelitian dan Pengabdian Kepada Masyarakat Universitas Katolik Parahyangan 